\title{
A sociolinguistic study of insulting in Wolof, Seereer, Mandingo and Pulaar communities in Senegal
}

\author{
Dr. Ibrahima Sarr \\ Université Gaston Berger de Saint-Louis (Sénégal) \\ UFR de Civilisations, Religions, Arts et Communication \\ Laboratoire Recherches Sociolinguistiques et Didactiques
}

\begin{abstract}
Sociolinguists have always tried to assess the relationship between language and society. In their works, however, some aspects of this relationship seem to be left to chance either because they are taboo or out of reach or are simply not interesting enough to them. What is undeniable is that one's integration in a foreign community depends largely on one's capacity to internalize the overall set of values. They also have to be careful not to overstep the bans. On the linguistic aspect, one of the most apparent of these bans is insulting; this is socially and morally shocking utterances meant to belittle the individual. This article focuses on the Senegalese society and seeks to highlight the sociolinguistic complexity of insulting. This implies an explicit definition of the concept, a study of its verbal and non verbal aspects, the semantic fields of insulting and its perception within society. Finally, we will study the factors that soften insults.
\end{abstract}

Key words: insult, ban, linguistic deviation, perception.

\section{INTRODUCTION}

In the linguistic sciences in general, and particularly in sociolinguistics, any communication situation is worth thinking about from the moment that it poses the five major issues "who says what, in what language or language variety, to whom, when , and where". The insult is a slip of the tongue, a ban which is constantly violated by the very members of the speech community that has classified it in "taboo" language. So, it becomes commonplace. But is there something more normal than the expression of a state of mind when we know that needs repressed escape sooner or later our control and may arise in forms worse than anything we feared? It is to reconsider the perception of insults that some do not hesitate to attribute them a cathartic power ( Bonvini, 1995; Bangré, 2003; Fisher, 2004). Thus Emilio Bonvini writes in his article untitled "les injures dans les sociétés africaines" (Terms of Abuse in African Societies) that in the Dogon ${ }^{1}$ and in other African societies, catharsis by mockery and insulting are common facts. Furthermore, it is institutionalized and it allows some people, in a given situation to mock at each other or insult ${ }^{2}$. The aim of such "verbal aggression" is to prevent social tensions. This paradox of prohibiting insulting on the one hand and institutionalizing it on the other hand is precisely what makes it a fascinating subject of study.

This article therefore seeks to investigate the above Senegalese communities to account for people's attitude vis-à-vis insulting, the different forms of insulting but also its targets, the imageries which are used when insulting, and the lexical field of insults. It also traces the border line between tolerated and prohibited insults.

\footnotetext{
${ }^{1}$ A people in Mali (West Africa)

${ }^{2}$ Emilio Bonvini. «Les injures dans les sociétés africaines » In Faits de langues vol.3, Nº. Paris : CNRS, 1995, p.154.
} 


\section{ABOUT DATA COLLECTION}

The data analyzed in this article were collected as a result of the field work which was carried out in two phases. The first is a library research that permitted to review some socio-cultural aspects of joking relationships and the social taboos such as linguistic taboos among ethnic groups in Senegal. The second phase corresponds to the collection of data; this was done through short interviews with young people, and old persons (men and women) who have a fairly good knowledge of verbal and non-verbal insults and their cultural connotations. The data were collected in the town of Saint Louis (Senegal), and the informants are selected among the Wolof, the Pulaar, the Serer and the Mandingo communities. Accessibility was the main criterion for the choice of the informants and they were interviewed in their ethnic language apart from the Pulaar with whom our limited competence compelled us to resort to a lingua franca i.e. Wolof. The respondents had to react on the following question:

$\checkmark$ What is insulting?

$\checkmark$ How is it perceived in ethnic community you belong to?

$\checkmark$ According to you in what lexical fields do people draw insults?

$\checkmark$ Are there some specific settings where insulting in tolerated?

$\checkmark$ Are insults only verbal or can they be non verbal?

$\checkmark$ Who is generally targeted when insulting?

\section{THE PERCEPTION OF INSULTING}

According to Le Petit Larousse, the insult is a word or an act that is intended to offend " une parole (ou, plus rarement, un acte) qui a pour objet d'outrager, d'offenser, de blesser la dignité ou l'honneur » and insulting means offending by hurtful words or derogatory offensive acts. This definition clearly places the insult in the register of social taboos since the offense of others is a crime, especially when they are poured out publicly and were not triggered by a preceding provocation. In Senegal, there is a measure in criminal law that focuses on the penalties weighing on those who are convicted of such an offense ${ }^{3}$. The conviction is unanimous because of the devastating effects of insulting and the threat it poses to social stability. For this reason also, Emilio Bonvini notes that the insult is felt by the African people as a deplorable language gap that impairs social cohesion. And for that, it should be banned in all its forms and by all means:

Les ethnolinguistes et les ethnologues ont souligné avec force combien les sociétés africaines condamnent cet écart de langage le considérant comme dangereux pour la vie collective et combien elles s'évertuent à le juguler au moyen de rituels de réparation, ou encore en l'institutionnalisant sous forme de «catharsis »4.

In this quotation, Bonvini states that ethnolinguists and anthropologists strongly emphasized how African societies condemn this language gap, considering it dangerous to community life, and how they strive to curb it through rituals, or by institutionalizing it as a "catharsis".

Understood as a word or an act that is intended to offend, insulting often occurs by reaction to another word or act which aroused anger in the individual who resorts to it. The latter thus loses his temper, which leads to verbal excess. It is for this reason that Sophie Fisher argues that "insulting is an act of language in the strict sense. It is punctual and appears as the burst of passion, excess, in verbal situation" 5 .

\footnotetext{
3 These measures can be found in Book III, Title II , Chapter I, Section VIII , Paragraph II of Senegalese criminal justice

4 Emilio Bonvini. « L'injure dans les langues africaines ». Op.cit.

${ }^{5}$ Sophie Fisher. « L’insulte : la parole et le geste » In Langue Française. Arman Colin, 2004/4 n¹44, p.53.
} 
The proscription of insulting is unanimous among Senegalese communities and resorting to it in exceptional circumstances can be a sign of lifting the prohibition. Therefore, even if Mamadou Drame tries to justify its use by focusing on its "healing power" and its identity dimension in Senegalese rap music, the fact remains that insulting is an obscene act. In fact it is one of the reasons that make that despite the richness of the lyrics, rap music has long suffered from marginalization in many social strata where it is considered too vulgar6.

\section{FORMS OF INSULTING}

Societies have always combined gesture and speech to make more effective communication. If individuals who have disabilities (i.e. the dumb) mainly rely exclusively on gestures to express themselves, other people can make a choice between verbal and non verbal language or a combination of both depending on the situation of communication. Thus, insulting explores these channels. It may be an act, or a gesture intended to produce the same effects as verbal abuse. In this regard, Sophie Fisher says that "when insulting is done in situ, it is usually accompanied by body movements"7. This view is clearly resonating with Emilio Bonvini who writes the following:

Il importe d'abord de souligner que la formulation linguistique n'est pas la seule forme possible de l'injure. Il est en effet possible d'injurier en utilisant exclusivement le corps comme support matériel de l'offense par le recours à la gesticulation, à la mimique et à divers signaux acoustiques (bruitage). Ces supports sont autonomes par rapport à la langue, même si leur utilisation accompagne et double souvent la formulation linguistique de l'injure ${ }^{8}$.

According to him, it should be noted that the linguistic formulation is not the only possible form of insulting. It is possible to insult using only the body as material support of the offense by the use of gestures, the facial expressions and various acoustic signals (sound effects). These supports are autonomous from the language, even if their use often accompanies the linguistic formulation of the insult.

However, these acts and gestures have a cultural dimension, so that their interpretation is relevant only if it applies to a specific culture. For example, in the Moor community of Senegal, the fact of brandishing a shoe to someone or throwing it at him is a very serious insult. It comes down to treating the individual in the worst meanness, and pettiness that one can imagine. Thus, this is exactly how journalists had to interpret the attitude of that Iraqi who threw a sandal at George W. Bush during his visit in Iraq. Also, the middle finger is a loan to Western culture and integrated the non-verbal language of youth charged with the same semantic value. Other forms of insults using sign language proliferate, especially among young people who demonstrate great creativity about it though these insults are not formalized. As for the elderly, they resort mainly to verbal insulting.

\section{THE TARGETS OF THE INSULTS}

With the exception of insults within the strict framework of joking, insulting is intended to produce an effect of shock and outrage at its target. As such, it targets the sensitivities of the existence of the individual as the objective is to hit where it hurts, emotionally. These are

\footnotetext{
${ }^{6}$ Mamadou Dramé. «L'obscène pour exorciser le mal en disant l'interdit : enjeux et signification des injures employées dans le rap au Sénégal » In Sudlangues $n^{\circ}$ 5. p.159. Retrived from http://www.sudlangues.sn/

7 Sophie Fisher. Op.cit. p.56.

8 Emilio Bonvini. Op.cit. p.157.
} 
naturally the intimacy or the elements on which the dignity and personality of the individual within the community are founded and the sacred links of parenthood. It is for this reason that Habibou Bangré notes that mothers, being highly sacred in most African countries, are the main targets of insulting even if fathers are not spared ${ }^{9}$. Grandparents are also targeted, especially in the context of insulting between people in a joke-relationship.

\section{SOCIAL RELATIONSHIPS FAVORABLE TO INSULTING}

It should be noted that despite its offensive nature, its banishment and its devastating effects, insulting is sometimes tolerated in certain social contexts. As Bangre observes, "insults flow based on sociological criteria"10. This means that in such a situation the object of the insult is not to hurt the person being insulted ${ }^{11}$, which brings us back to wonder if there really is an intrinsic connection between insulting as signifier and the sense of shock that often results seizes the insulted person. It seems obvious that it is rather the sum of insulting and social relationship between the insulting person and the insulted one that is able to trigger this feeling. In other words, there are kinds of social relationships favorable to insulting and others which are not. In Wolof ${ }^{12}$, the phrase "seqqunuko ${ }^{13 "}$ that corresponds to the seereer ${ }^{14}$ one "indeeriran" is often heard from the first deviant speech and constitutes a clear verbal warning of the speaker against his interlocutor language gaps. By cons joking relationships are more tolerant to insulting because of their socio-cultural dimension.

Cousinship : In the Senegalese tradition, your cousins are children of your mother's brother and those of your father's sister. You can thus get along and have a friendly relationship. If we are to use that definition, it must be noted then, that the meaning of 'cousinship' is more restrictive in the Senegalese society than in the West where the terms "uncle" and "aunt" include both the father's brother and the mother's sister. The father's brother is considered as one's own father in Senegalese culture and is called 'small dad' while the mother's sister is considered as one's own mother and is called 'little mum'. As a matter of fact, their children see themselves not as cousins as it would have been in Western cultures but as brothers and sisters.

Senegal is a Muslim majority country and polygamy is a common marriage pattern. Because the sharing of a same husband is likely to arise tension between co-wives; these are therefore allowed to maintain a friendly relationship and get along well. This is meant to assure peaceful coexistence between members of the society. Such kinds of joke relationships are firmly established by the society and are so well rooted in the philosophy of the people that they resists expletives. Better yet, the expletives are for certain people ingredients that give the relationship its originality and ability to create some joy and harmony in the life of the community. Some types of insults are then allowed if they do not reach the parents.

\footnotetext{
${ }^{9}$ Habibou Bangré. Op.cit.

10 Habibou Bangre. « Guide pratique des insultes en Afrique » retrieved from http://www.afrik.com/article6498.html

11 This is called Sinankuyaa in Mandinka, maasir in Seereer, kal in Wolof, and dendiraagal in Pulaar.

12 Wolof is the demographically dominant local language in Senegal (West Africa). It is estimated that 45 percent of the people speak it as a mother tongue while another 50 percent to whom it serves for a lingua franca use it as a second language. These striking feagures have led many researchers to see it as the language of national identity. 13 Literally "I do not allow you to say such things to me"

14 Seereer is the third language in Senegal in terms of number of speakers, behind Pulaar. It is estimited that its ethnic group makes 14 percent of the Senegalese population while the linguistic group is 12 only percent. Such an imbalance is due to language shift in favor of Wolof through the phenomenon known as Wolofisation.
} 
Other joke relationships: these are other situations favorable to insulting. According to Marie-Aude Fouéré who gives a classic definition, the joke relationship refers to specific relations that are established either between some members of a kinship group, or between clans or lineages, or even between ethnic groups. These relationships involve the adoption of specific behaviors such as saying jokes or teasing and performing acts of assistance ${ }^{15}$.

Joking relationships cover a very broad range of relationships that may include, for example, members of the same family (Cousins) or ethnicity (e.g between the Seereer and the Pulaaror the Diola or between the Mandingo and the Bambara and Diola) 16 between people with specific surnames ( Diouf and Faye; Ndiaye and Diop; Diarra Traoré, etc. )17 . In this regard, Cécile Canut and Étienne Smith note the following:

Tant au plan de la spécification des groupes et individus impliqués dans la relationrelations entre cousins croisés, oncles maternels et neveux utérins, petits-enfants et grands-parents, beaux-frères et belles-sœurs, classes d'âges alternées, matriclans, patriclans, groupes socioprofessionnels, maîtres et captifs, quartiers, villages, contrées, entités politiques, labels patronymiques, noms d'honneurs, groupes désormais «ethniques» -, que de l'intensité de la relation connexe - alliance matrimoniale préférentielle ou interdit de mariage, pacte de sang réel ou pacte de sang métaphorique, simples moqueries ou relation sanctionnée par une "amende», liberté de ton complète ou plaisanteries minimales, humour gratuit ou service attendu -, ou de son orientation - de la symétrie à l'asymétrie -, c'est indiscutablement l'hétérogénéité qui caractérise cet ensemble de relations qui ont, tour à tour, été versées dans le champ, décidément trop vaste, des "relations à plaisanterie »18.

So, according to them, both in terms of the specification of groups and individuals involved in the relationship and the intensity of the associated relationship or its orientation, it is unquestionably that actually it is the heterogeneity that characterizes this set of relationships which have been termed "joking relationships".

Just as cousinship, the joking relationship establishes types of behavior that are original and plays an important role in the cohesion in groups. Thus Marie-Aude Fouéré states that "The most striking feature of these relationships [joking relationships] refers to the behavior of joking partners. When they meet, they insult each other and can even fight"19. The same is customary in Pulaar society where cousins can slander and mock each other and simulate a relationship of cheerful antagonism. However, proponents of this form of relationship must be taken to avoid any form of hostility between them..$^{20}$

\section{LEXICAL FIELDS OF INSULTING}

If insulting means to offend, to harm by uttering hurtful words, then we can already imagine the immensity of the semantic fields that is covered by insults all the more as it is open to all

\footnotetext{
15 Marie-Aude Fouéré. «Les métamorphoses des « relations à plaisanteries » : Un nouvel enjeu politique dans la construction des États-nations » In Cahiers d'études africaines 2005/2, 178, p.391.

16 These are different ethnic groups in Senegal.

17 All of these are Senegalese common family names.

${ }^{18}$ Cécile, Cécile et Étienne Smith, « Pactes, alliances et plaisanteries », Cahiers d'études africaines, 184 | 2006, URL: http:// etudesafricaines.revues.org/6198, p.3.

19 Marie-Aude Fouéré. « Les métamorphoses des « relations à plaisanteries ». Ibid. p.192

20 Yaya Wane. Les Toucouleurs du Fouta Tooro : stratification sociale et structure familiale. Collection Initiations et études africaines ${ }^{\circ} \mathrm{xxv}$. Dakar : IFAN, 1969, p.150.
} 
areas of life. However, there are more constant fields and this is what we want to discuss about in this section of our work.

\section{The imageries of domestic and wild animals}

We will open this section by passing a sample of the online daily Nettali.net which reported in an article titled " Djibo Ka : the insult" the words of the former Senegalese minister under the presidency of Leopold S. Senghor and Abdou Diouf. His words were deemed offensive to the now ruling coalition "Benno Bokk Yaakaar": Here is the quote:

"Enough is enough," shouted the former minister. "We want to mark the occasion with this boycott ... Bokk Yakaar is not a parliamentary group. Moreover, a woman belonging to this parliamentary group called it "gett" (Editor's note : flock, in Wolof). That made me laugh." Djibo Ka clarify his thinking: "This means that it is composed of sheep, goats and even wild animals. ${ }^{21 "}$

What is considered offensive in this passage is where Djibo Ka voluntarily hgihlights the women MP`s intended meaning, and interprets her words as implicitly equating members of the parliamentary group of Benno bokk Yaakaar to a sheep, goats and other wildlife. To grasp the hidden meaning of this statement, we will do a small study on the imageries of these animals in Senegalese society.

The imagery of the sheep: the sheep is a mammal ruminant with sometimes ringed horns that is raised in Senegal for nutritional needs. In a country like France, a person can be as gentle as a lamb or be a scabby or be a black sheep. If the first expression can be taken for a quality, it is clear that the other two clearly have negative connotations. In Senegal, the extreme sweetness of a person is rather seen as a sign of innocence. Sheep therefore reflects the image of a being of extreme simplicity, which has no consciousness to understand life and who has no personal initiative. Its mode of expression is the bleating which also has a negative connotation as synonymous to annoying cries. To this end, the Wolof word "mbélélélé coow $l a^{\prime 22}$ is devoted to the bleating to mean that it is but idle chatter. In individuals treated as sheep, naivety and lack of initiative lead him to blindly execute everything they are ordered to do. This construction is exactly what the French call "mouton de panurge". As far as the lack of awareness is concerned, it pushes the person to follow his instincts and act instinctively. Finally, the inability to produce a meaningful discourse makes that one's contribution to the group is not only vain, but worse, it is even disturbing. Moreover, treating someone as a sheep means ignoring his humanity and reducing his being to animality.

The imagery of the goat: the goat is a small ruminant whose horns are curved back. Certain breeds of goats are wild while others are not. In Senegal, it is mainly the domestic breed we see everywhere. As the sheep, it is mainly bred for meat and milk. While the French expression "devenir chevre" bears the meaning of getting upset or impatient and has nothing insulting, in the Senegalese socio-cultural reality, to call a person a goat can provoke a reaction all quite surprising because of what that animal connotes. The goat, especially the he goat, indeed reflects the image of a womanizer. It also reflects the image of a being who is not calm and who moves a lot or who is wacky. Above all, it is the image of a person who lacks discretion. Therefore to treat someone as a goat in the Senegalese cultural context is to assume that he is bizarre and restless and intrusive. The common point of these labels is that they are flaws and all fall, thus, into social deviations.

${ }^{21}$ Djibo Ka : l'insulte. http://www.nettali.net/article.php3?id_article=26391 [my translation]

${ }^{22}$ Mbelelele is an onomotopeia used for the bleating of the sheep. 
The image of the cow: This is the breeding female of the bovine species. If the image Senegalese society associates with the male (the bull) is that of a strong and powerful person, this is not the case for the cow. The cow reflects the image of a being who cannot see beyond his nose. Its simplicity is legendary and leads to have blind faith in things around it, so that it does not sniff the blows of betrayal, does not recognize the hypocrites and believes everything it hears without the further thought. It does not have a sixth sense, which is the ability to feel things before they actually occur. The cow is also the image of a being that is not awake. In French, we have a few phrases devoted to the cow. A person that one easily exploits, who gives money to others is called "cow milk" while one very nasty and ruthless is a "peau de vache" 23 .

Apart from these three cases, there are other animals which imageries are often used to hurt the dignity of a person. In Senegalese society, some of these pets are, for example dogs and cats. While we associate the same attributes as the sheep to the former, the image that society gives the latter is quite different.

The imageries of the dog and the puppy: the dog is a domestic mammal of which there are a large number of races. In the Senegalese cultural context, people who are often treated dog are those who commit stupidities, or promiscuous people because, they say, while the cat fights out of breath before giving in to the male sexual assault, the bitch gives of itself without any trouble. To call a person a dog thus, returns to treat him of a fool, of wanton and easy-going. As the Seereer saying goes "o koor faapum a noonaa", ${ }^{4}$ thus the puppy will inherit traits from his father. In addition to the defects that affect the dog, the puppy is seen as a bastard or worse as someone whose father is unknown because the dog has mated with several partners and ultimately, no one knows which of them is actually the biological parent of his youngs. So in Wolof society, the phrase "doomu Xaj" ( puppy ) returns to mean four things, all of which are insulting: to the person`s mother (one implies that the person`s mother is a loose woman); to the father (that his father a philanderer) to the person himself (that he has mild manners which results from the genes he inherited from his parents - and that he is a bastard).

The imageries of the kitten: to understand the image that Senegalese society gives the kitten, one must revisit local customs. The female cat must deliver a bitter battle with the male cat to mate. What was to be an intimacy and a moment of happiness for the female cat is then done in the most total indiscretion and coercion. The mating of the two could be likened to a rape, should human laws should apply to animals. Yet, in the Senegalese socio-cultural reality, a child born of a sexual relationship where the woman has collapsed under the weight of the constraint imposed by man cannot blossom, or thrive socially. Therefore to call someone a kitten (doomu wund ${ }^{25}$ ) returns to tell him that he is cursed and condemned to a life of misery as a result of "the sinful act of forcing one's partner to have sexual intercourse" committed by both parents.

In the light of the different perceptions that Senegalese society has about the animals we listed as examples, we can now easily understand the reasons why Djibo Ka's statement could offend the sensibilities of some of his countrymen, especially his political friends in power. They (supporters of the ruling party) did not, however, wait to respond to the dimension of the "offense". Indeed, one of them known as Lifa wrote the following by way of response: "But in

${ }^{23}$ A cowhide.

${ }^{24}$ Like a father like a son.

25 The Wolof term for kitten. 
our parliamentary group there is no mad cow as somebody called you"26. To measure the scope of this reply, it should be noted that treating someone a mad cow implies that they are brainless, stupid. Indeed encephalopathy is chronic neurological and psychological disorders resulting from damage of the nervous system. In Senegal, however, there is often a big gap between the intent of insulting and the truth about the personality of the people being insulted. Things are often said just to hurt and actually what hurts is that the audience might think that what was said about you is true while it might be totally wrong.

\section{Human biological organs}

Insulting may consist of the mere naming of some organs of the individual. Those organs are exclusively private parts. In normal language, we resorted to euphemisms to name these because they are taboo in Senegalese society. This is a sign of respect that mitigates the shock effect that the raw word would produce. However, the insulter rarely use euphemisms for the simple reason that the intention behind the act of insulting excludes any mark of respect and sensitivity to the impact of his words. The insulting comes from the fact that in Senegalese society everything that relates to sexuality and sexual organs is listed in the register of linguistic taboos. The following table shows the organs and orifices commonly referred to when insulting, in four Senegalese communities. Forms in bold are the euphemisms that are sometimes used, but in the case of insulting, resorting to the euphemism does not diminish the impact of the insulting.

\begin{tabular}{|c|c|c|c|c|}
\hline & the penis & $\begin{array}{c}\text { The Vulva and the } \\
\text { vagina }\end{array}$ & The anus & the testicles \\
\hline Wolof & kooy, dambal, kuur ${ }^{27}$ & $\begin{array}{l}\text { bajo, cottu, lëf, data, } \\
\text { caapa, kanam }\end{array}$ & bun, tuun, gat & xuur \\
\hline Seereer & $\begin{array}{l}\text { i raađ, i juul, đeek; o } \\
\text { dog }^{28}\end{array}$ & i đex, i njub, o jot & o suus, o ruy & a co', a paam \\
\hline Pulaar & solde & kottu & rumođo & \\
\hline Mandin & $\begin{array}{l}\text { fotoo, jakaroo, solo, } \\
\text { kurutujuloo' } 29\end{array}$ & beya, bewo, juwo, buto & $\begin{array}{l}\text { buruđewo, buuđaa, } \\
\text { kutuđaa, juuđaa }\end{array}$ & kiloo, berekiloo \\
\hline
\end{tabular}

Table1: organs which naming is considered insulting

\section{The status and attributes}

People's status may also be subject to insulting. As such, in hierarchical societies, where there is a caste system, some castes are victims of marginalization and exclusion. So calling a person the name of members of a caste considered lower than that to which he belongs can normally be taken as insulting, especially when society has a negative perception of that caste.

In a country like Nigeria, the Osu are treated as slaves. In the capital city of the Gambia, Banjul, there is an area called "afday ${ }^{30 "}$ where slaves beaten and half dead were confined. In Senegal, some architecture in the historic town of Saint- Louis ${ }^{31}$ and Gorée say enough about the

\footnotetext{
${ }^{26}$ Lifa's response to a user of internet supporting Djibo Ka's point about the parliamentary group of the ruling party and its allies. Retrieved from http://www.nettali.net/article.php3?id_article=26391

27 The pestle.

28 The stick.

29 The rope that is in the pair of trousers.

30 It originates from the English « half-dead"

31 A town in northern Senegal which used to be the capital city of the country. It has been successively occupied by the Portuguese, the English and the French. Now it is a tourist destination because of its historical aspect which earns it to be classified as a world heritage.
} 
condition of their former occupants whose descendants have now become great dignitaries. However, slavery is the worst form of exploitation of man by man, the condition of a slave is seen as a shame because it deprives the individual of his dignity by belittling him to the lowest level of existence. Treating a person as a slave by extension to a previous condition of his ancestors is a grave insult in the Senegalese cultural context. It should be noted that with the diachronic evolution of languages, the word slave has underwent an extension of meaning to connote the betrayal and deprivation of pride. Here is a list of words corresponding to slave in different Senegalese communities: Wolof (jaam) seereer (o pad) Pulaar (maccuđo), Mandingo (Jongo) etc.

The prosecution of acts against nature is also an insult in Senegalese societies. Witchcraft is an act against nature and in the past, those who were convicted of witchcraft were often extirpated from society and forever expelled from the village. They shunned like the plague. Their girls were not taken into marriage nor their sons could marry unless outside the communities where they were known. This means therefore that accusing someone of witchcraft is a serious insult that tarnishes his image and that of all the people she is biologically related, especially the mother's side, because they say that witchcraft is a gene transmitted from parent to child through breast milk.

Similarly, homosexuality is considered an act against nature. In the Wolof community, the mere fact of being effeminate for a man (not necessarily gay) makes him being mocked in the community ${ }^{32}$. The evocation of certain anomalies and diseases may hurt some individuals because of the perception that society has about them. So it is considered as insulting. The catalog of insults is thus enriched when one says a man he is impotent or when one says a man he has aids. Aids and other sexually transmitted infections are traditionally called "shameful disease" in Senegalese society. The shame comes from the fact that one of the causes of these infections is non abstinence or unprotected sex with multiple partners. This then implies that there is either unfaithfulness to one's partner if already married to someone else or they will be addicted to sex before marriage. The former and the latter being prohibited by the society and listed in the register of social deviations, thus provoking shame to the victim and any reference to them is considered as insulting.

\section{CONCLUSION}

The lexical field of insulting in Senegalese society is very rich because it offers a well-stocked repertoire. It includes among its members men and animals by the images associated with them. They are issued by the verbal or non-verbal channel but any of these channels has a mitigating effect on the emotional shock triggered by the insult. These expletives are however perceived differently according to sociological variables such as social relationships. Thus, insults uttered in the context of a joking relationship are not perceived as such while outside this framework it becomes completely unacceptable. Finally, "the slanderer" targets sensitivities of the person being insulted such as the elements that have forged his human dignity and the sacred kinship ties.

32 One can still recall President Macky Sall's response to journalist asking if Senegal was ready to legalize homosexuality during President Obama's visit in August 2013 in Dakar. 


\section{BIBLIOGRAPHY}

Achard, Pierre. La sociologie du langage 2ème édition. Paris : PUF, 1993.

Bangre, Habibou. « Guide pratique des insultes en Afrique » http://www.afrik.com/article6498.html

Bonvini, Emilio. «L'injure dans les langues africaines » In Faits de langues vol.3, N6. Paris : CNRS, 1995, pp.153162.

Canut, Cécile et Étienne Smith, « Pactes, alliances et plaisanteries », Cahiers d'études africaines, 184 | 2006, URL : http:// etudesafricaines.revues.org/6198, pp.1-44. (Consulté le 05 décembre 2012).

Code Pénal Sénégal. Livre III, Titre II, Chapitre I, Section VIII, Paragraphe II : Calomnies, injures, révélation de secrets.

Coinaniz, Alain. Langages, cultures, identités. Paris : L'Harmattan, 2005.

Delpech, B. Terme de parenté en pays seereer (Baol, Sine, Petite Cote). Dakar: ORSTOM, (sans date).

Djibo Ka : l'insulte. http://www.nettali.net/article.php3?id_article=26391 (consulté le 12 décembre 2012).

Dramé, Mamadou. «L'obscène pour exorciser le mal en disant l'interdit : enjeux et signification des injures employées dans le rap au Sénégal » In Sudlangues n 5. pp.157-173 pdf. http://www.sudlangues.sn/

Fisher, Sophie. « L'insulte : la parole et le geste » In Langue Française. Arman Colin, 2004/4 n¹44. pp.49-58 http://www.cairn.info/revue-langue-francaise-2004-4-page-49.htm (Consulté le 1 décembre 2012).

Fouéré, Marie-Aude. «Les métamorphoses des « relations à plaisanteries » : Un nouvel enjeu politique dans la construction des États-nations » In Cahiers d'études africaines 2005/2,178, p.389-430.

http://www.cairn.info/article.php?ID_REVUE=CEA\&ID_NUMPUBLIE=CEA_178\&ID_ARTICLE=CEA_178_0389

Le Petit Larousse illustré. Paris : Larousse, 1997.

Mané, Mamadou. La dynamique des brassages culturels dans l'espace du kaabu. (Actes du colloque sur les convergences culturelles au sein de la nation sénégambienne). Kaolack : 1994.

Morris, Charles. Signification and Significance. Cambridge : The Massachusetts Institute of Technology Press, 1964.

Niane, Djibril Tamsir. « La culture mandingue, facteur d'intégration sous-régionale ouest africaine» In Ethiopiques n57-58. 1993, pp.89-93.

Wane, Yaya. Les Toucouleurs du Fouta Tooro : stratification sociale et structure familiale. Collection Initiations et études africaines ${ }^{\circ} \mathrm{xxv}$. Dakar : IFAN, 1969. 